\title{
A Reflective Practitioner: An Undeniable Urgent Role for EFL Teachers in Digital Era
}

\author{
Absharini Kardena ${ }^{1}$ \\ ${ }^{1}$ English Education Section, Institut Agama Islam Negeri (IAIN) Bukittinggi, Indonesia \\ *absharinikardena@yahoo.co.id
}

\begin{abstract}
This study aims to investigate the phenomenon on how English teachers run their roles as a reflective practitioner. It was analyzed based on the way the teachers reflect their teaching activities; how the English teachers evaluated their performance, their students and their class; how the English teachers spend efforts to improve their competence and performance. Moreover, this research, which was further developed based on research conducted on 2014, involved 5 English teachers at MAN Kota Solok, one of Islamic state senior highs school in Solok City. The research was conducted under qualitative approach through observing those English teachers and compiled by such interviews. The result shows that the English teachers at this school did not optimally run their role as reflective practitioner. It cannot be denied that many factor beyond the teachers itself which influences this phenomenon. This article discusses this phenomenon significantly in order to give a consideration for the stakeholder and the English teachers in making any decisions related to teachers' role as a reflective practitioner and its impact on achieving the educational goals, especially in this digital era.
\end{abstract}

Keywords: Digital Teaching; Digital Education; EFL

\section{Introduction}

Nowadays, being English teachers is a challenging profession ever, especially in digital era. The English teachers should be able to counterbalance the access of information which is now categorized as easy-access information, including for the students. Hence, the English teachers are not only demanded to stand in front of the class and directly teach the students there. Nowadays, the concept of teaching has been moved from only standing in front of the class and then sharing knowledge into a more complete task. The English teachers are demanded to plan their class as a beginning step of teaching, including setting the goals, the materials, the media, teaching technique and so on. In order to plan this role, surely the teachers should gather information about students' needs and interest the so that the teachers is able to choose the appropriate techniques, materials and media used in the classroom[1]. Moreover, they should be able to transfer the knowledge into the students during the teaching process in the classroom and it is ended by the evaluation process as the last stage. In this stage, the teachers should evaluate not only the students but also themselves.

In evaluation stage, mostly teachers do evaluation for the students through many tasks and tests given. In fact, the teachers should also be able to evaluate more than just giving tests and tasks. They should be able to reflect any actions taken in the classroom so that they can develop their critical reflective teaching process[2]. The reflection itself consists of two 
elements; evaluating the teaching process and doing the research[3]. According to Kojima and Kojima, the English teachers are responsible to evaluate all aspects in the classroom[3]. They said the teachers are a reflective practitioner and researcher. In this case, the teachers demands to reflect and evaluate teaching and learning process. It includes self-improvement, selfdevelopment, and also understanding the context in which the teaching and learning takes place. At the end, it aims to improve the quality of teaching and learning in educational context. It is linear to the idea stated by Mathers in which she explains that teachers' evaluation could be used as a tool to promote teachers professional growth and to measure teachers effectiveness in the classroom[4]. In a more depth explanation, the teachers is demanded to evaluate teaching and learning process in order to measure his/ her successful in the classroom.

In a more detail explanation, Mathers stated that there are two kinds of evaluation for the teachers[4]. They are formative evaluation and summative evaluation. Both of those evaluations are different in several points. It is explained by Mathers as follow:

Formative evaluations are meant to provide teachers with feedback on how to improve performance and what types of professional development opportunities will enhance their practices. Summative evaluations are used to make a final decision. Although both types of evaluations seek to measure performance, the formative evaluation identifies ways to improve performance and summative evaluation determines whether the performance has improved sufficiently such that the teachers can remind in his or her current position and be rewarded for performance. Without formative feedback, a teachers may not be informed of "areas of weaknesses" so when the summative evaluation takes place, these "areas of weaknesses" may still exist. Similarly, ongoing formative evaluations without any consequences provide minimal incentives for teachers to act on the feedback[4].

The evaluation done by the teachers as explained above is a kind of evaluation conducted to measure students' achievement while it also aims to see the successful of teaching process. Besides, the teachers are also demanded to improve any weaknesses during their teaching process as it is the goal of doing the evaluation. Moreover, reflection in teaching can give a big picture of In order to evaluate teaching and learning process, the teachers are suggested to conduct a research as a source of idea to improve EFL teaching[5]. As explained by Kojima and Kojima:

The interdependence of reflective research and teaching is a foundation stone of EFL education. Precisely because research into student learning has studied and described the conditions that are necessary for changes in student understanding. it provides a promising source of ideas for EFL teaching. These insights help us to decide on the best ways to organize the curriculum. evaluate teaching in order to encourage improvement, and plan satisfactory programs for helping individual teachers teach better[3].

Derived from those roles, Meece develops some points that demand the teachers to do some actions[6]. He says that the teachers should organize a meaningful learning activity. The way the teachers organizes the learning activity may influence the development of teaching and learning processes in foreign language classes, especially in English[7]. It is aimed to provide complex and challenging learning activities that promote conceptual and analytical thinking. In line with organizing learning activity, the teachers are also expected to help students to develop their understanding and critical thinking. Thus, any learning activities that are developed should be based on a concept of building students' critical thinking. It could be done through offering an opportunity for students to work in group or peers so that it can encourage their autonomy in learning and increase their responsibility for their own learning. 
Furthermore, Meece also explains that the teachers should be able to use a variety of instructional strategies and methods to match students' needs and culturally relevant to the students[6]. Moreover, an instructional strategy, which also known as a teaching strategy, is a technique or method which is used as guidance in taking any actions in the classroom which aims to achieve the learning goals[8]. In other words, the teachers should choose and then evaluate any teaching strategies used in the classroom and analyze how effective the strategies used to achieve the learning goals which have been set.

The last point that is explained by Meece is the teachers should be wise in deciding the assessment to the students[6]. The assessment must be able to measure students' competence and achievement in using the language in a variety of ways. It is expected that the teachers can monitor students' progress and offer any feedback for the students through the assessment given. In order to run the function of the assessment itself, the teachers should realize the assessment has multifaceted functions in teaching and learning processes. It gives a big impact on the students; progress and also can give a reflection for the teachers about teaching activity in the classroom[9]. The most important one is the teachers should also realize that the use of assessment must be varied because different assessment may measure different aspects of students' learning progress[10].

By considering the roles of the English teachers above, it can be stated that the role of the teachers as a reflective practitioner is an undeniable role, especially for EFL teachers. In fact, the preliminary research conducted at MAN kota Solok, an Islamic senior high school at Solok city, West Sumatera province, showed that mostly the English teachers did not concern on their role as a reflective practitioner. It was known from preliminary observation in which only few of the teachers took any actions needed related to evaluating their teaching process. The dominant action was about evaluating students' achievement only.

Based on this phenomenon, this article is developed to know analyze how the teachers exactly did their role as a reflective practitioner. This article discusses how they run this role and its impact on the achievement of education goal.

\section{Methodology}

This research was conducted under qualitative approach by using phenomenology design. The research was conducted in order to find out how the English teachers evaluate their performance and analyze the reflection of their teaching process. Thus, the informants of this research were all English teachers at MAN (Islamic senior high school) at Solok city, West Sumatera, Indonesia. The data were gathered through observation and interview to the English teachers. The observation was conducted 5 times for each of the teachers. The researcher played as passive observer in which the researcher did not interrupt any actions taken in the classroom. The teachers were observed based on two items; there were evaluating teaching process and doing research. Moreover, the teachers were also interviewed in order to validate and strengthen the data from observation. The interview was conducted several times for each teachers and it was ended when the data collected have been saturated. The interviews were done as a kind of semi-structured interview. The data, then, were analyzed by using the theory from Patton under the phenomenology analysis[11]. Here the steps followed during analyzing the data:

1. The researcher transcript the data collected from the interview. 
2. The researcher differentiated between participants' opinion and fact on the data gotten from the interview. In other words, the researcher had to be able to clarify any personal bias from the data collected.

3. The researcher tabulated the data from the observation.

4. The researcher gathered the purely data which related to the research. Any other data that was not about the research should be put out. Moreover, the researcher got the real facts of the data.

5. The researcher grouped the data based on the main questions of the research.

6. The researcher interpreted the meaning of the phrases or statements from the interview and participants' activity during the observation.

7. The researcher described the deeper meaning of participants' statements from interview and activity from the observation.

The results of the observation and interview were studied and analyzed to see how the teachers reflect their teaching process.

\section{Result and Discussion}

The data of the research were gathered through observation and interview. The informants of the research were observed and then interviewed based on the phenomenon found during the observation. Here below is the data gotten from the observation to five English teachers as the informants of the research. The observation was conducted 5 times for each of the teachers. The data related to this role were stated in the table 1.

Table 1. Teachers' Performance as a Reflective Practitioner and Researcher

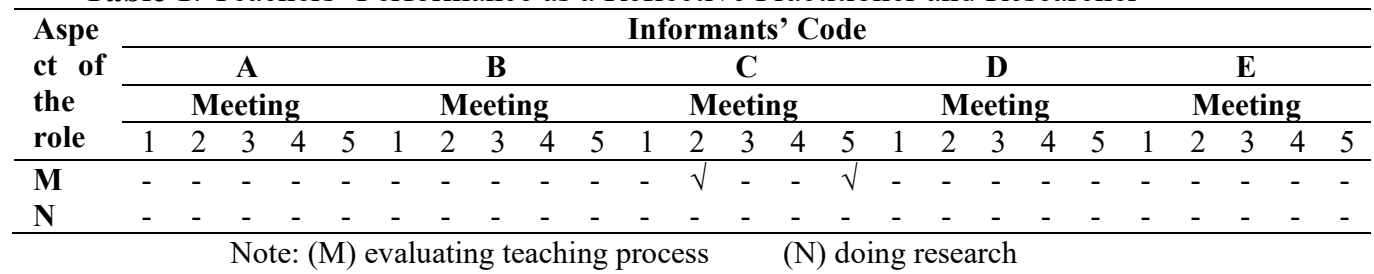

Table 1 clearly described that none of the teachers did such kind of research for improving the quality of teaching and learning process. Besides, it also proved that there was only one teacher who evaluated their teaching process twice from 5 meetings observed. Indeed, 4 of 5 teachers in every meeting never revised any technique or materials that they used. It was observed that the teachers did not evaluate their own work. They did not review whether the students were interested on the technique or materials. They also did not evaluate how far the technique that they used increased students' achievement. It was proved from the data collected through observation that those teachers always used the same technique in every meeting for different classes. It means that the teachers did not reflect whether the technique that they used have given a significant improvement for the learners' achievement.

In addition, the fact showed that there was only one teacher who evaluated the way he monitored students' progress on their own group. It has been noticed that this teachers became more intensive in monitoring students' progress and their contribution on their own group. Based on the interview with these teachers, he stated that he always reflected what he did 
during teaching and learning process in every meeting in every class. The transcript for the interview was stated in interview 1.

Interview 1:

R: Nah kalau evaluasi proses pembelajaran dari sisi si guru bagaimana pak?

T: Kalau saya punya konsep seperti ini, kalau siswa bingung saya akan pertanyakan materi suliat atau saya yang tidak bisa menyampaikan. Kan itu saja. Kurang tepatkan strategi kita atau materinya yang terlalu berat untuk mereka. Itu mengevaluasi diri saya kan seperti itu. Kemudian kan nanti ada juga dating dari senior, supervisor kan ada juga. Cuma supervisor itu jarang dating dan saya termasuk yang malang karena saya juga jarang disupervisi. Kecendrungannya menyupervisi kelas yang anak-anaknya banyak keluar kelas. Nah kalau saya kan... yah syukurlah anak-anak betah di dalam kelas. Jadi saya jarang yang disupervisi. Yang penting kan pertahankan power kita, pertahankan strategi kita. Terkadang kita iya juga capek ya.

R: Nah tadi bapak bilang kalau evaluadi diri dilihat dari materi atau strategi mengajar. Nah bagaimana bapak menentukan yang mana ternyata yang bermasalah?

T: Nah lihatlah persentasenya. Anak sudah menguasai mayteri atau tidak. Nah lihat, kalau anak yang kurang menguasai kan kita dekati itu. Kalau sekarang kan system remidi. Kalau saya sebelum meremidi, saya dekati siswa dulu. Tanya pakai bahasa Indonesia saja apa masalahnya. Nanti akan terungkap. Pak itu materinya terlalu sulit. Nah mari bapak bantu satu kali lagi. Kalau memang tidak juga setelah dua kali, saya anggap materinya sulit bagi dia. Nah nanti saya cari jalan tengah. Nah kan bisa saja untuk yang lain materinya ini, untuk siswa yang khusus ini materinya diturunkan sedikit. Kan bisa saja itu.

Translation of Interview 1:

R: How do you evaluate yourself in teaching?

$\mathrm{T}$ : I have a concept. When the students are confused, I will ask myself whether the materials or the teaching technique that is not appropriate. The, there is also a supervisor although s/he rarely comes. I am seldom observed. S/he tends to supervise the teachers in which the students often go out of the classroom, but I don't. The important one is we keep our power and our strategy although we are sometimes tired.

$\mathrm{R}$ : How do you decide whether the problem is on the materials or teaching technique?

T: Based on the percentage of how many students have acquired the materials. The students who get low score will be asked indirectly to know whether the material is quite difficult for them or not. When they do not understand, I'll re-teach it. If they still get bad mark, it means that the material is difficult for them.

The data from the interview above proved that the evaluation of teaching and learning process that usually done by this teacher was done through self-correction. The points that were usually evaluated by the teachers were the materials and the technique that was used in teaching. From the interview, it could be interpreted that the teachers did several approach to 
the students in order to see whether the problems was on the materials or the technique used; the materials were more difficult for some students or the technique was not interactive and interesting for the students.

The data from the interview above proved that the role of the teachers as a reflective practitioner was influenced by their role as a decision maker, especially for deciding materials and teaching technique. The result of their evaluation gave such reflection to the teachers on the level of the materials and teaching technique that $\mathrm{s} /$ he used. In other words, self-evaluation that was done by the teachers gave him/her input about the decision of materials and teaching techniques that were going to be used for the next teaching and learning process. In other words, teachers' reflection on learning materials and teaching technique may influence the next decision they make in their teaching process[1].

Besides, from the observation done, all the English teachers in this school never did any small research related to teaching and learning process. This situation strength the previous explanation that the teachers never evaluated the way they taught in the classroom. The interview done with the teachers also proved that the teachers rarely wrote a classroom action research as a way to evaluate their teaching and learning process and as a tool to improve students' achievement. The transcript of the interview was stated in interview 2.

Interview 2:

R: Penelitian perlu dilakukan ndak buk untuk situasi seperti ini? PTK atau apalah.

T: Ya masih perlu. Perlu. Biasanya dilakukan, yang bisa dilakukan satu kali, satu kali dalam 6 bulan. Harusnya dalam 3 bulan harus selesai satu., tapi ya... kita ndak selalu bisa.

Translation of interview 2:

R: Do you think a research should be conducted? such as classroom action research?

T: Yes. It is needed. Usually, I do it once in 6 months. Actually it should be done at least once in 3 months.

The data of the interview above describe that the teachers only did one research in one semester. Although the teachers knew that she needed to do it often, she still did not do it because of limitation of time that she had. In other words, the teachers did not evaluate their teaching and learning process through doing a research, especially classroom action research.

Through analyzing the interview, it can be known that there was a main cause of this phenomenon. The cause of this phenomenon was because of no evaluation system that was used by the teachers for evaluating students' work. The teachers did not use a clear and designed scoring rubric for evaluating students' work. As a result, the score that was given to the students contained a high degree of bias. Based on the data collected, the teachers argued that they did not use it in order to give a higher score to the students rather than the truth score. It was aimed to increase students' motivation. The impact of this phenomenon was none selfevaluation done by the teachers because most of the students' score were high. In other words, the teachers did not do any reflection of their teaching and learning processes because they did not have the purely data of students' ability. What they knew was the students passed the standard score for English subject.

The effect of this phenomenon was related to the other roles of the teachers in EFL class. The aim of being a reflective practitioner is to give a reflection for the teachers about their performance so that they get an input and feedback for their future performance. The 
reflection included their other roles such as an information gatherer, a decision maker, a motivator, a facilitator of group dynamics, a provider of opportunities for communicative and authentic language used, a counselor, and a promoter of multicultural perspectives. However, since the teachers did not do their role as a reflective practitioner and researcher, they were not able to evaluate their other roles. The effect was they did not get any feedback and correction for their future performance. As a result, they were also not able to optimize students' effort to get a better achievement. In other words, doing reflection in teaching process is an urgent action since it influences the future performance of teachers in teaching and learning processes. Simply, it impacts on the future chosen materials, media, teaching techniques and even the assessment used. Thus, it cannot be denied that this role, being a reflective practitioner, is an important thing for the English teachers.

In other words, it can be stated that teachers' role as a reflective practitioner and researcher influenced the other roles of the teachers. At the end, it also influences students' motivation and their achievement because any reflection and evaluation that was done by the teachers automatically affected the process of teaching and learning process in the classroom.

The fact that should be realized based on this research was the teachers did not evaluate their teaching process or even did such kind of research. In other words, they did not develop their teaching competence and performance. It might affect teachers' ability in teaching. It is explained by Farrell in which he says "teachers who engage in reflective practice can develop a deeper understanding of their teaching, assess their professional growth, develop informed decision-making skills, and become proactive and confident in their teaching.[12]" Beside the reason proposed by Farrell above, Kojima and Kojima also argue that the teachers are demanded to reflect and to evaluate teaching and learning process[3]. It is aimed for helping the teachers do self-improvement, self-development and also understanding the situation that they faced in teaching and learning process every day. Because of that, the teachers are really demanded to play their role as a reflective practitioner.

\section{Conclusion}

Being English teachers mean being able to answer the challenging of teaching students in digital era. Since the students can access everything easily and fast, the teachers should be able to accommodate students' needs. One of the ways is through doing their role as reflective practitioner. The teachers have to reflect all their actions in the classroom through evaluating the teaching process and take any decisions based on the result through doing the research. The performance of the teachers in conducting this role generally may affect the way the teachers perform on their other roles. Thus, the English teachers are suggested to run their role as a reflective practitioner optimally.

\section{References}

[1] A. Kardena, "Teacher's Role as An Information Gatherer: A Hidden Part in Developing Learning in Context," 2017.

[2] S. B. Gutierez, "Teachers' reflective practice in lesson study: A tool for improving instructional practice," Alberta J. Educ. Res., vol. 61, no. 3, pp. 314-328, 2015.

[3] H. and Y. K. Kojima, "Teacher roles in learner-centered communicative EFL 
instruction," 2005. [Online]. Available: http://repository.ul.hirosakiu.ac.jp/dspace/bitstream/10129/544/1/AN00211590_94_59.pdf. [Accessed: 04-Jun2012].

[4] C. Mathers and M. Oliva, "Improving Instruction through Effective Teacher Evaluation: Options for States and Districts. TQ Research \& Policy Brief.," Natl. Compr. Cent. Teach. Qual., no. February, 2008.

[5] A. Sööt and E. Viskus, "Reflection on Teaching: A Way to Learn from Practice," Procedia - Soc. Behav. Sci., vol. 191, no. June, pp. 1941-1946, 2015.

[6] J. Meece, "Applying learner-centered principles to middle school education," Theory Pract., vol. 42, no. 2, pp. 109-116, 2009.

[7] J. and E. E. Martin, "The Importance of Organisation and Classroom Management in Foreign Language Teaching," Int. J. Learn., vol. 12, no. 3, pp. 259-275, 2005.

[8] G. Ayua, "EFFECTIVE TEACHING STRATEGIES," 2017.

[9] A. Wach, "Classroom-based language efficiency assessment: a challenge for EFL teachers," Glottodidactica. An Int. J. Appl. Linguist., vol. 39, no. 1, p. 81, 2012.

[10] I. and A. S. Widiastuti, "FORMATIVE ASSESSMENT IN EFL CLASSROOM PRACTICES," J. Bahasa, Sastra, Seni dan Pengajaran, vol. 45, no. 1, pp. 50-63, 2017.

[11] Q. Patton, Qualitative Evaluation and Research Methods. London: Sage Publication Itd, 1990.

[12] T. S. C. Farrell, "Brief reflective practice in the professional development of teachers of adult English language learners," CAELA Netw., no. October, pp. 1-4, 2008. 